\title{
The Relationship of Thyroid Nodules with Total Serum IgE Level and Metabolic Parameters in Patients with Hashimoto Thyroiditis
}

\author{
Hashimato Tiroiditli Hastalarda Tiroid Nodülünün Total Serum IgE Düzeyi ve \\ Metabolik Parametreler ile Ilișkisi
}

(1) Idris Kalkan, (10 Hanife Usta Atmaca, (D) Feray Akbaş

University of Health Sciences Turkey, İstanbul Training and Research Hospital, Clinic of Internal Medicine, İstanbul, Turkey

\begin{abstract}
Introduction: The literature demonstrates elevated immunoglobulin $\mathrm{E}$ (IgE) levels in autoimmune thyroid diseases and their relationship with allergic diseases. The purpose of this study was to describe the relationship between thyroid nodules and total serum IgE levels and metabolic parameters in patients with Hashimoto thyroiditis.

Methods: The study included 627 Hashimoto thyroiditis patients [500 (female: 406, male: 94) with and 127 (female: 101, male: 26) without thyroid nodules] and 292 (female: 224, male: 68) healthy control patients. Total serum IgE levels, metabolic parameters, fasting blood glucose (FBG), hemoglobin $\mathrm{A} 1 \mathrm{C}(\mathrm{HbA} 1 \mathrm{c})$, total cholesterol, low-density lipoprotein cholesterol, triglyceride, uric acid, free-T4, free-T3, thyroid stimulating hormone, anti-thyroglobulin, anti-thyroid peroxidase, C-reactive protein (CRP) levels, and sedimentation rate were measured in all groups. Moreover, SPSS was used to analyze the results.
\end{abstract}

Results: The mean age, serum IgE levels, mean FBG, HbA1c, and CRP levels of the thyroid nodule group were statistically significantly higher than the non-nodule and control groups $(p<0.05)$. In all Hashimoto thyroiditis patients, metabolic parameter levels were statistically significantly higher than in control groups $(p<0.05)$

Conclusion: There is a significant relationship between serum total IgE levels and thyroid nodules. Furthermore, thyroid nodule development appears to be influenced by metabolic and inflammatory abnormalities. These findings confirm the presence of multisystem factors in the development of thyroid nodules.

Keywords: Hashimoto thyroiditis, serum total IgE level, thyroid nodules

\section{ÖZ}

Amaç: Tiroid nodülü ile alerjik hastalıklar ve yüksek immünoglobulin E (IgE) arasındaki ilişki çeşitli çalışmalarla gösterilmiștir. Burada Hashimato tiroidit tanılı hastalarda tiroid nodülleri ile total serum IgE düzeyi ve metabolik parametereler arasındaki ilişkinin gösterilmesi amaçlanmıștır.

Yöntemler: Çalışmaya 16-78 yaş arası toplam 500 (406 kadın, 94 erkek) tiroid nodülü olan ve 21-73 yaș arası 127 (101 kadın, 26 erkek) tiroid nodülü olmayan toplam 627 hashimato tiroidit tanılı hasta ile 17-76 yaş arası 292 (224 kadın, 68 erkek) kontrol hastası dahil edilmiștir. Tüm hasta ve kontrol gurubunda total serum IgE düzeyi serum metabolik parametreler [açlık kan şekeri (AKŞ), hemoglobin A1c (HbA1c), total kolestrol, düșük yoğunluklu lipoprotein-kolesterol, trigliserit), ürik asit, T4, T3, tiroid stimüle edici hormon, anti-tiroglobulin, C-reaktif protein (CRP) değerleri bakılmıștır

Bulgular: Tiroid nodüllü hasta grubunun yaş ortalaması ve serum IgE ortalaması, nodülsüz hasta grubu ve kontrol grubuna göre istatistiksel olarak anlamlı şekilde yüksekti $(p<0,05)$. Nodüllü hasta grubunda AKȘ, HbA1c ortalaması ve CRP düzeyi kontrol grubu ve nodülsüz hasta grubuna göre anlamlı yüksekti $(p<0,05)$, Tüm Hashimato hasta grubunda (grup 1 ve grup 2) metabolik parametreler (total-kol, LDL- Kol, Trigliserit, sedimentasyon, ürik asit) düzeyleri kontrol grubuna göre anlamlı yüksekti $(p<0,05)$.

Sonuç: Bu çalıșma serum total IgE düzeyi tiroid nodül varlığı arasında güçlü bir ilișki olduğunu aynı zamanda bazı metabolik ve enflamatuvar parametrelerdeki anormalliklerin tiroid nodül olușumuna katkısı olabileceği gösterilmiștir. Bu durum nodül oluşumunda bazı sistemik nedenlerin varlığını ortaya koyduğunu destekler niteliktedir.

Anahtar Kelimeler: Hashimato tiroidit, serum total IgE düzeyi, tiroid nodül 


\section{Introduction}

Hashimoto thyroiditis is an autoimmune disease characterized by the presence of specific autoantibodies against the thyroid gland. Endogenous causes, as well as genetic and environmental factors, contribute to its etiology. Moreover, its prevalence increases with age and female gender. During the course of the disease, nodule development is common. Thyroid nodules are often found during clinical investigations and imaging procedures, and they are significant due to their malignant potential (1). In addition, thyroid nodules are defined by the American Thyroid Association as "thyroid gland lesions which are radiologically distinct from thyroid parenchyma" (2). In the adult population, its prevalence is estimated to be $20-76 \%$ by ultrasonography (USG) $(1,3,4)$ and $50-60 \%$ in autopsy series (5). Autoimmunity, radiation exposure, genetics, and iodine consumption all play a role in its etiology.

IgE is an antibody that is important in the pathogenesis of allergic diseases. In individuals who are susceptible, antigen-presenting cells (macrophages, B lymphocytes) phagocytose antigens and present them to CD4+ T-lymphocytes in the context of molecules of class II major histocompatibility complex. T-lymphocytes develop a specific sensitivity to these allergens and turn to specific T-lymphocyte subgroup clones. T-helper lymphocytes produce immunoglobulin E (IgE) via interleukin-4 (IL-4) and other cytokines. IgE has been linked to both autoimmune thyroid diseases (AITD) and allergic diseases. Further, IgE levels were found to be elevated, especially in Graves' disease (6-8). The high prevalence of chronic urticaria in AITD patients (9) and the specific IgE development against thyroid peroxidase (TPO), which has been shown to play a role in chronic urticaria pathogenesis $(10,11)$, suggest a strong relationship between thyroid diseases and IgE. However, no studies on the effect of IgE on nodule development have been conducted in AITD.

The purpose of this study was to investigate the effect of IgE on nodule development in Hashimoto thyroiditis patients, as well as the relationship between thyroid nodule presence and inflammatory and metabolic parameters.

\section{Methods}

\section{Study Subjects}

The study included 500 (female: 406, male: 94, age: 16-78) Hashimoto thyroiditis patients with ultrasonographically proven thyroid nodule presence, 127 (female: 101, male: 26, age: 21-73) Hashimoto thyroiditis patients without thyroid nodules, and 292 (male: 224, female: 68, age: 17-76) healthy subjects as the control group. Moreover, the study was designed to recruit patients from an internal medicine outpatient clinic in a systematic and prospective manner. Smoking, excessive alcohol intake, medication other than for thyroid diseases, and the presence of any other accompanying diseases were all exclusion criteria.

The study protocol was approved by the University of Health Sciences Turkey, İstanbul Training and Research Hospital Clinical Research Ethics Committee (approval number: 1950, date: 09.08.2019).

\section{Measurement of Biochemical Parameters}

Fasting blood glucose (FBG), triglycerides, C-reactive protein (CRP), uric acid, IgE, total cholesterol, and low-density lipoprotein (LDL) cholesterol were analyzed using a biochemistry analyzer (Beckman Coulter AU 2700) (Beckman Coulter Inc., Brea, USA). In addition, hemoglobin A1C (HbA1c) parameter was analyzed on the Premier Hb9210 HPLC analyzer (Trinity Biotech, Ireland).

The levels of anti-thyroglobulin, TPO, thyroid stimulating hormone (TSH), free-T4, and free-T3 were analyzed using an immunoassay analyzer [Beckman Coulter DXI 800 (Beckman Coulter Inc., Brea, USA)]. On the other hand, the erythrocyte sedimentation rate was analyzed using the Berkhun SDM-100 Auto-instrument (Turkey).

\section{Thyroid Evaluation}

Thyroid USG was performed by an experienced radiology specialist using a SSA-770A, Aplio 300 ultrasound machine (Toshiba Medicals, Otawara, Japan) equipped with a 7-15 MHz linear transducer (PLT-1204AT; Toshiba Medical Systems).

Radiological reports of thyroid nodules were reviewed using PACS data of our institution. A thyroid nodule is a discrete lesion that is distinct from the surrounding thyroid parenchyma. The maximum diameter of a thyroid nodule was measured in three planes: longitudinal, transverse, and anteroposterior. Further, these detailed reports included sonographical behavior (hypoechogenicity vs hyperechogenicity), cystic or solid components, calcifications, contour properties, and peripheral vascular halo integrity.

\section{Statistical Analysis}

For categorical variables, descriptive statistics were reported as a number and percentage, while numerical variables were reported as mean, standard deviation, minimum, maximum, and median. The Kolmogorov-Smirnov test was used to determine the distribution of variables. For the analysis of quantitative independent data, the Kruskal-Wallis $\mathrm{H}$ and Mann-Whitney $\mathrm{U}$ tests were used. For the analysis of qualitative independent data, the chi-square test was used. The statistical alpha significance level was regarded as $p<0.05$. Moreover, the statistical analysis was carried out using SPSS 22.0 for Windows program.

\section{Results}

The study included a total of 919 patients: 500 Hashimoto thyroiditis patients with thyroid nodules (group 1), 127 Hashimoto thyroiditis patients without thyroid nodules (group 2), and 292 healthy subjects as the control group (group 3).

Table 1 displays laboratory and clinical data from all groups.

The mean age of group 1 was statistically significantly higher than groups 2 and $3(p<0.05)$, and the mean age of group 2 was statistically significantly higher than group $3(p<0.05)$ (Table 1$)$.

FBG, HbA1c, IgE, and CRP levels in group 1 were statistically significantly higher than in groups 2 and $3(p<0.05)$. There was no statistically significant difference in these values between groups 2 and 3 (Table 1).

In groups 1 and 2, uric acid, LDL cholesterol, triglyceride, and sedimentation rates were statistically significantly higher than in group $3(p<0.05)$. There was no statistically significant difference in these values between groups 1 and 2 (Table 1). 
In groups 1 and 2, the fT3 level was statistically significantly lower than in group 3. However, there was no significant difference in fT3 levels between groups 1 and 2 ( $p>0.05)$ (Table 1$)$.

In group 2, TSH, anti-TPO, and anti-TG levels were statistically significantly higher than in groups 1 and $3(\mathrm{p}<0.05)$. These values were statistically significantly higher in group 1 than in group $3(p<0.05)$ (Table 1$)$.

In group 1, there was no correlation between IgE levels and anti-TPO $(p=0.862)$ and anti-TG $(p=0.882)$ levels. Also, there was no correlation between IgE level and anti-TPO $(p=0.766)$ and anti-TG $(p=0.194)$ levels in group 2 (Table 2).

\section{Discussion}

This study showed that there could be a relationship between thyroid nodules, serum IgE levels, and metabolic and inflammatory parameters in Hashimoto thyroiditis patients. The mean IgE level was found to be $128 \mathrm{UI} / \mathrm{mL}$ in most patients and $200 \mathrm{UI} / \mathrm{mL}$ or higher in $3 \%$ of thyroid nodule patients. In the non-nodule group, the mean IgE level was only $49 \mathrm{UI} / \mathrm{mL}$. This difference was statistically significant, implying that IgEmediated allergic reaction could be contributing to nodule formation.

IgE is a critical factor in allergic reactions. In studies, the contribution of IgE-mediated inflammation in the AITD development and reactivation

Table 1. Laboratory and clinical data of all groups

\begin{tabular}{|c|c|c|c|c|c|c|c|c|}
\hline & & \multicolumn{2}{|l|}{ Group 1} & \multicolumn{2}{|l|}{ Group 2} & \multicolumn{3}{|l|}{ Group 3} \\
\hline & & Mean $\pm \mathrm{SD} / \mathrm{n},(\%)$ & Med & Mean \pm SD/n, (\%) & Med & Mean $\pm \mathrm{SD} / \mathrm{n},(\%)$ & Med & $p$ \\
\hline \multicolumn{2}{|l|}{ Age } & $53.8 \pm 13.8$ & 55.0 & $47.9 \pm 14.2$ & 47.0 & $44.2 \pm 16.1$ & 45.0 & $0.001^{\mathrm{K}}$ \\
\hline Gender & Male & $94(18.8 \%)$ & - & $26(20.5 \%)$ & - & $68(23.3 \%)$ & - & $0.320 \chi^{2}$ \\
\hline \multicolumn{2}{|l|}{ FBG } & $107.5 \pm 34.1$ & 99.0 & $99.8 \pm 22.3$ & 95.0 & $102.2 \pm 28.3$ & 95.0 & $0.001^{\mathrm{K}}$ \\
\hline \multicolumn{2}{|l|}{ CRP } & $0.8 \pm 2.0$ & 0.3 & $0.5 \pm 0.7$ & 0.2 & $0.5 \pm 1.0$ & 0.2 & $0.001^{\mathrm{K}}$ \\
\hline \multicolumn{2}{|l|}{ Urea } & $30.2 \pm 10.0$ & 28.0 & $27.2 \pm 7.7$ & 26.0 & $27.9 \pm 10.1$ & 26.0 & $0.001^{\mathrm{K}}$ \\
\hline \multicolumn{2}{|l|}{ Uric acid } & $5.2 \pm 1.5$ & 5.1 & $5.0 \pm 1.3$ & 4.9 & $4.8 \pm 1.4$ & 4.5 & $0.001^{\mathrm{K}}$ \\
\hline \multicolumn{2}{|l|}{ Creatinin } & $0.7 \pm 0.2$ & 0.7 & $0.7 \pm 0.2$ & 0.7 & $0.7 \pm 0.2$ & 0.7 & $0.570^{\mathrm{K}}$ \\
\hline \multicolumn{2}{|l|}{ Cholesterol } & $215.9 \pm 47.3$ & 214.0 & $215.5 \pm 54.8$ & 220.0 & $201.7 \pm 46.0$ & 194.0 & $0.001^{\mathrm{K}}$ \\
\hline \multicolumn{2}{|l|}{ FT3 } & $3.3 \pm 0.6$ & 3.3 & $3.4 \pm 0.8$ & 3.3 & $3.4 \pm 0.6$ & 3.4 & $0.009^{k}$ \\
\hline \multicolumn{2}{|l|}{ FT4 } & $0.9 \pm 0.2$ & 0.9 & $0.9 \pm 0.3$ & 0.9 & $0.9 \pm 0.3$ & 0.9 & $0.195^{\mathrm{K}}$ \\
\hline \multicolumn{2}{|l|}{ TSH } & $2.9 \pm 8.7$ & 1.6 & $7.4 \pm 18.1$ & 2.7 & $2.6 \pm 6.6$ & 1.8 & $0.001^{\mathrm{K}}$ \\
\hline \multicolumn{2}{|l|}{ Anti-TPO } & $85.6 \pm 232.9$ & 1.2 & $276.0 \pm 349.2$ & 109.1 & $1.5 \pm 3.4$ & 0.7 & $0.001^{\mathrm{K}}$ \\
\hline \multicolumn{2}{|l|}{ Anti-TG } & $31.5 \pm 140.6$ & 0.9 & $105.1 \pm 329.0$ & 9.2 & $4.1 \pm 51.0$ & 0.9 & $0.001^{\mathrm{K}}$ \\
\hline \multicolumn{2}{|l|}{ Sedim } & $21.5 \pm 15.1$ & 18.0 & $20.4 \pm 13.1$ & 17.0 & $18.9 \pm 15.2$ & 14.5 & $0.007^{\mathrm{K}}$ \\
\hline \multicolumn{2}{|l|}{$\mathrm{Hb} 1 \mathrm{Ac}$} & $6.0 \pm 1.0$ & 5.8 & $5.8 \pm 0.8$ & 5.6 & $5.9 \pm 1.0$ & 5.7 & $0.001^{\mathrm{K}}$ \\
\hline \multicolumn{2}{|l|}{ WBC } & $7.2 \pm 2.4$ & 7.0 & $7.1 \pm 1.6$ & 7.0 & $7.2 \pm 1.8$ & 7.0 & $0.676^{\mathrm{K}}$ \\
\hline
\end{tabular}

Table 2. Relationship between IgE level and thyroid auto-a

\begin{tabular}{|l|l|l|l|l|}
\hline & Group 1 & Group 2 & \\
\hline & Anti-TPO & Anti-TG & Anti-TPO & Anti-TG \\
\hline IgE & 0.008 & 0.007 & -0.027 & 0.116 \\
\hline & 0.862 & 0.882 & 0.766 & 0.194 \\
\hline
\end{tabular}

Spearman correlation. TPO: Thyroid peroxidase, TG: thyroglobulin, IgE: immunoglobulin E 
has been discussed. Elevated IgE levels were found particularly in Graves' disease (30-40\%) and Hashimoto thyroiditis (20.8\%). However, in other studies, a similar elevation was not found, which was thought to be due to ethnically low rates of allergic diseases $(7,12,13)$.

Several studies involving chronic urticaria and AITD implicated IgE in thyroid autoimmunity (14-16). This data was supported by another study that showed a high prevalence of Hashimoto thyroiditis in chronic urticaria patients and thyroid hormone replacement reduced urticaria symptoms (17). However, no studies have been conducted to demonstrate the effect of IgE on nodule formation in AITD.

Total serum IgE secretion is found on chromosome $5 q 31$, which also contains some cytokines $(18,19)$. IL-13 is an anti-inflammatory cytokine that induces and preserves IgE production and IgE-mediated allergic responses (20). Moreover, $64.7 \%$ of patients with high IgE levels also have high IL-13 (7). IL-4 and IL-13 share biologic activity that promotes IgE secretion. Concomitant secretion of IgE and cytokines increases the inflammation and may contribute to thyroid nodule formation.

Impaired fasting glucose, insulin resistance, and lipid abnormalities are all components of metabolic syndrome, which is a major cause of cardiovascular morbidity and mortality. Elevated FBG is associated with type 2 diabetes mellitus (DM), insulin resistance, elevated insulin levels, and a defect of insulin usage at peripheral tissues, and these tissues are susceptible to its proliferative effect. In our study, FBG, HbA1c, and lipid parameters were significantly higher in the nodule group than in the non-nodule group. Other studies have found a link between glucose metabolism disorder and thyroid nodule presence. Wang et al. (21) discovered a relationship between insulin resistance and thyroid nodule size (21). According to other studies, thyroid volume and nodule prevalence increased in type $2 \mathrm{DM}$ and impaired fasting glucose (IFG) $(22,23)$. TSH, insulin-like grow factor-1, and insulin function as mitogenic factors, promoting thyroid nodule formation (24).

IFG and related hyperinsulinemia facilitate cell proliferation. HbA1c levels, metabolic syndrome parameters, and thyroid nodules all showed a positive correlation. It is assumed that hyperinsulinemia, hyperglycemia, and hyperlipidemia cause nodule formation through thyroid proliferation and angiogenesis (25-27).

TSH is directly involved in thyroid cell growth and differentiation, as well as nodule formation (28). Although some studies concluded that TSH could not be used solely as a mitogenic factor (29), others found a strong correlation between thyroid volume and TSH $(22,30)$. Its elevation is important because it increases the risk of malignancy in the presence of thyroid nodules. In our study, TSH levels were normal in the nodule group but elevated in the control group. It was normal in the nonnodule group as well, but it was still higher than in the nodule and control groups when compared (Table 1).

Other studies showed that elevated TSH in normal range was associated with an increased risk of thyroid nodule and malignancy $(31,32)$, implying that TSH could affect thyroid gland and nodule formation even in the normal range. Normal TSH levels in this case could be due to suppression of hyperfunctioning nodules or outsourced hormonal therapy.

\section{Conclusion}

Metabolic and inflammatory factors as well as many others contribute to thyroid nodule formation. This study showed a possible relationship between serum IgE levels and thyroid nodules. We contend that the prevalence of thyroid nodules may increase in the presence of IgEmediated allergic diseases and atopy. Thus, patients with allergies and atopy should be screened for thyroid pathologies using imaging studies as well as blood tests.

Acknowledgments: We would like to thank the biochemistry and radiology clinics of our hospital for their contribution to the study.

Ethics Committee Approval: The study protocol was approved by the University of Health Sciences Turkey, İstanbul Training and Research Hospital Clinical Research Ethics Committee (approval number: 1950, date: 09.08.2019).

Informed Consent: All subjects provided informed consent.

Peer-review: Externally and internally peer-reviewed.

Authorship Contributions: Surgical and Medical Practices - I.K., H.U.A., F.A.; Concept - H.U.A., F.A.; Design - F.A.; Data Collection or Processing - I.K.; Analysis or Interpretation - H.U.A.; Literature Search - H.U.A.; Writing - H.U.A., F.A.

Conflict of Interest: No conflict of interest was declared by the authors.

Financial Disclosure: The authors declared that this study received no financial support.

\section{References}

1. Mazzaferri EL. Management of a solitary thyroid nodule. N Engl J Med 1993; 328: $553-9$

2. American Thyroid Association (ATA) Guidelines Taskforce on Thyroid Nodules and Differentiated Thyroid Cancer, Cooper DS, Doherty GM, Haugen BR, Kloos RT, Lee SL, Mandel SJ. Revised American Thyroid Association management guidelines for patients with thyroid nodules and differentiated thyroid cancer. Thyroid 2009; 19: 1167-214.

3. Ezzat S, Sarti DA, Cain DR, Braunstein GD. Thyroid incidentalomas. Prevalence by palpation and ultrasonography. Arch Intern Med 1994; 154: 1838-40.

4. Tan GH, Gharib H. Thyroid incidentalomas: management approaches to nonpalpable nodules discovered incidentally on thyroid imaging. Ann Intern Med 1997; 126: 226-31.

5. Mortensen JD, Woolner LB, Bennett WA. Gross and microscopic findings in clinically normal thyroid glands. J Clin Endocrinol Metab 1955; 15: 1270-80

6. Sato A, Takemura Y, Yamada T, Ohtsuka H, Sakai H, Miyahara Y, et al. A possible role of immunoglobulin E in patients with hyperthyroid Graves' disease. J Clin Endocrinol Metab 1999; 84: 3602-5.

7. Yamada T, Sato A, Komiya I, Nishimori T, Ito Y, Terao A, et al. An elevation of serum immunoglobulin E provides a new aspect of hyperthyroid Graves' disease. J Clin Endocrinol Metab 2000; 85: 2775-8.

8. Kim HY, Park KR, Kim SH, et al. The relationship between Graves' disease and serum immunoglobulin-E. J Korean Society Pediatric Endocrinology 2002; 17: 640-8.

9. Kim YS, Han K, Lee JH, Kim NI, Roh JY, Seo SJ, et al. Increased Risk of Chronic Spontaneous Urticaria in Patients with Autoimmune Thyroid Diseases: A Nationwide, Population-based Study. Allergy Asthma Immunol Res 2017; 9: 373-7. 
10. Altrichter S, Peter HJ, Pisarevskaja D, Metz M, Martus P, Maurer M. IgE mediated autoallergy against thyroid peroxidase--a novel pathomechanism of chronic spontaneous urticaria?. PLoS One 2011; 6: e14794.

11. Shin YS, Suh DH, Yang EM, Ye YM, Park HS. Serum Specific IgE to Thyroid Peroxidase Activates Basophils in Aspirin Intolerant Urticaria. J Korean Med Sci 2015; 30: 705-9.

12. Komiya I, Yamada T, Sato A, Kouki T, Nishimori T, Takasu N. Remission and recurrence of hyperthyroid Graves' disease during and after methimazole treatment when assessed by IgE and interleukin 13. J Clin Endocrinol Metab 2001; 86: 3540-4.

13. Latifi-Pupovci H, Gacaferri-Lumezi B, Lokaj-Berisha V. There is no elevation of immunoglobulin e levels in Albanian patients with autoimmune thyroid diseases. J Thyroid Res 2014; 2014: 283709.

14. Verneuil L, Leconte C, Ballet JJ, Coffin C, Laroche D, Izard JP, et al. Association between chronic urticaria and thyroid autoimmunity: a prospective study involving 99 patients. Dermatology 2004; 208: 98-103.

15. Levy Y, Segal N, Weintrob N, Danon Y. Chronic urticaria: association with thyroid autoimmunity. Arch Dis Child 2003; 88: 517-9.

16. Cebeci F, Tanrikut A, Topcu E, Onsun N, Kurtulmus N, Uras AR. Association between chronic urticaria and thyroid autoimmunity. Eur J Dermatol 2006; 16: $402-5$.

17. Sugiyama A, Nishie H, Takeuchi S, Yoshinari M, Furue M. Hashimoto's disease is a frequent comorbidity and an exacerbating factor of chronic spontaneous urticaria. Allergol Immunopathol (Madr) 2015; 43: 249-53.

18. Marsh DG, Neely JD, Breazeale DR, Ghosh B, Freidhoff LR, Ehrlich-Kautzky E, et al. Linkage analysis of IL4 and other chromosome $5 q 31.1$ markers and total serum immunoglobulin E concentrations. Science 1994; 264: 1152-6.

19. Xu J, Levitt RC, Panhuysen Cl, Postma DS, Taylor EW, Amelung PJ, et al. Evidence for two unlinked loci regulating total serum IgE levels. Am J Hum Genet 1995; 57: 425-30.

20. de Vries JE. The role of IL-13 and its receptor in allergy and inflammatory responses. J Allergy Clin Immunol 1998; 102: 165-9.

21. Wang K, Yang Y, Wu Y, Chen J, Zhang D, Mao X, et al. The association between insulin resistance and vascularization of thyroid nodules. J Clin Endocrinol Metab 2015; 100: 184-92.
22. Duran AO, Anil C, Gursoy A, Nar A, Inanc M, Bozkurt O, et al. Thyroid volume in patients with glucose metabolism disorders. Arq Bras Endocrinol Metabol 2014; 58: 824-7.

23. Junik R, Kozinski M, Debska-Kozinska K. Thyroid ultrasound in diabetic patients without overt thyroid disease. Acta Radiol 2006; 47: 687-91.

24. Rapp K, Schroeder J, Klenk J, Ulmer H, Concin H, Diem G, et al. Fasting blood glucose and cancer risk in a cohort of more than 140,000 adults in Austria Diabetologia 2006; 49: 945-52.

25. Shin J, Kim MH, Yoon KH, Kang MI, Cha BY, Lim DJ. Relationship between metabolic syndrome and thyroid nodules in healthy Koreans Korean J Intern Med 2016; 31: 98-105.

26. Yin J, Wang C, Shao Q, Qu D, Song Z, Shan P, et al. Relationship between the Prevalence of Thyroid Nodules and Metabolic Syndrome in the IodineAdequate Area of Hangzhou, China: A Cross-Sectional and Cohort Study. Int J Endocrinol 2014; 2014: 675796.

27. Iribarren C, Haselkorn T, Tekawa IS, Friedman GD. Cohort study of thyroid cancer in a San Francisco Bay area population Int J Cancer 2001; 93: 745-50.

28. Rapoport B, Chazenbalk GD, Jaume JC, McLachlan SM. The thyrotropin (TSH) receptor: interaction with TSH and autoantibodies. Endocr Rev 1998; 19: 673716.

29. Vella V, Sciacca L, Pandini G, Mineo R, Squatrito S, Vigneri R, et al. The IGF system in thyroid cancer: new concepts. Mol Pathol 2001; 54: 121-4.

30. Ertek S, Cicero AF, Caglar O, Erdogan G. Relationship between serum zinc levels, thyroid hormones and thyroid volume following successful iodine supplementation. Hormones (Athens) 2010; 9: 263-8.

31. Haymart MR, Repplinger DJ, Leverson GE, Elson DF, Sippel RS, Jaume JC, et al. Higher serum thyroid stimulating hormone level in thyroid nodule patients is associated with greater risks of differentiated thyroid cancer and advanced tumor stage. J Clin Endocrinol Metab 2008; 93: 809-14.

32. Fiore E, Vitti P. Serum TSH and risk of papillary thyroid cancer in nodular thyroid disease. J Clin Endocrinol Metab 2012; 97: 1134-45. 